\title{
Congratulations to George Inzelt on the occasion of his 75th birthday
}

\author{
Fritz Scholz ${ }^{1}$ (D) Gyözö G. Láng ${ }^{2}$
}

Received: 23 August 2021 / Revised: 23 August 2021 / Accepted: 24 August 2021 / Published online: 28 October 2021

(c) The Author(s) 2021

With this special issue of the Journal of Solid State Electrochemistry, the electrochemical community congratulates George (György) Inzelt, Eötvös Loránd University Budapest, Hungary, on the occasion of his 75th birthday on November 2nd, 2021! His achievements have been dignified in this journal on the occasion of his 65th and 70th birthday. It is certainly a rare case to see a scientist honoured for the 3 rd time by papers from leading laboratories of the world. Because of the previous editorials $[1,2]$, we will not repeat here what has been written, but let the dedicated papers speak for themselves. Of course, George Inzelt stayed active also after his formal retirement, by publishing, lecturing, supervising $\mathrm{PhD}$ students and by giving advice to young colleagues as professor emeritus and head of the Laboratory of Electrochemistry and Electroanalytical Chemistry at the Institute of Chemistry of ELTE.

This issue is also a farewell to George as Topical Editor of this journal which he has helped to steer for more than 2 decades. We all hope that George will continue to give us help and advice in future. We wish him many years to come!

Funding Open Access funding enabled and organized by Projekt DEAL.
Open Access This article is licensed under a Creative Commons Attribution 4.0 International License, which permits use, sharing, adaptation, distribution and reproduction in any medium or format, as long as you give appropriate credit to the original author(s) and the source, provide a link to the Creative Commons licence, and indicate if changes were made. The images or other third party material in this article are included in the article's Creative Commons licence, unless indicated otherwise in a credit line to the material. If material is not included in the article's Creative Commons licence and your intended use is not permitted by statutory regulation or exceeds the permitted use, you will need to obtain permission directly from the copyright holder. To view a copy of this licence, visit http://creativecommons.org/licenses/by/4.0/.

\section{References}

1. Scholz F, Vorotyntsev MA (2011) J Solid State Electrochem 15:2277-2278

2. Láng GG (2016) J Solid State Electrochem 20:2913-2916

Publisher's Note Springer Nature remains neutral with regard to jurisdictional claims in published maps and institutional affiliations.

Fritz Scholz

fscholz@uni-greifswald.de

Gyözö G. Láng

langgyg@chem.elte.hu

1 Institut für Biochemie, Universität Greifswald, Felix-Hausdorff-Str. 4, 17489 Greifswald, Germany

2 Department of Physical Chemistry, Institute of Chemistry Laboratory of Electrochemistry and Electroanalytical Chemistry, Eötvös Loránd University, Pázmány P. s. 1/A, 1117 Budapest, Hungary 